\title{
多重歯翼溝の解析的クリープ破断寿命予測 ${ }^{\dagger}$
}

\author{
安藤 清* 竹 田 頼 正 ${ }^{*}$ 金子 晨* \\ 竹添堅三郎** 中島 慶 一* 川本和 夫*** \\ Analytical Creep Rupture Life Prediction \\ of Multiple-Lug Rotor Steeples
}

by

\author{
Kiyoshi ANDO*, Yorimasa TAKEDA*, Akira KANEKO* \\ Kenzaburo TAKEZOE**, Keiichi NAKASHIMA* ${ }^{*}$ and Kazuo KaWAMOTO***
}

An analytical prediction method of brittle and ductile creep rupture lives was proposed for $1 \mathrm{CrMoV}$ steel multiple-lug rotor steeples which have a tendency of degradation in creep ductility after long-term service. Rupture time was evaluated as a sum of crack initiation life and crack growth life with consideration of creep ductility and load-carrying factors of multiple-lugs in the steady creep state.

This method was experimentally verified by creep rupture tests of notched thick plate specimens and interrupted creep tests and microstructure observation of notched thick plate specimens and blade-root and rotor-steeple models at $600^{\circ} \mathrm{C}$. Two kinds of $1 \mathrm{CrMoV}$ steel in creep ductility were tested. The main conclusions are as follows.

1) An estimation method of load-carrying factors of multiple-lugs in the steady creep state was proposed and a uniforming tendency of load-carrying factors was recognized in the present models.

2) An estimation method of creep stress at the lug root with consideration of the stress-dependent creep strain rate was proposed for damage analysis and its validity was verified.

3) Creep rupture life of $1 \mathrm{CrMoV}$ rotor steeples can be evaluated in a practically reasonable accuracy as a sum of creep crack initiation life and creep crack growth life with consideration of creep ductility and load carrying factors of multiple-lugs in the steady creep state.

Key words : Creep, Crack initiation, Crack growth, Rotor steeples, $1 \mathrm{CrMoV}$ steel

\section{1 緒言}

既設火力プラントの長寿命化に伴い，設備診断なら びに寿命延長技術の開発扔よび精度向上の要求が強く なっている. 歴史的に翼溝クリープ損傷事故例をみる と, $1 \mathrm{CrMoV}$ 鍛鋼を高中圧ロータ材として使用し始 めた極く初期の 1950 年代の中頃に発生した Weadock ロー夕破損事故等がある. 交の原因はクリープ破断に 扔ける切欠き弱化によると考えられ，材料の熱处理改 善による切欠き弱化傾向の軽減と許容応力の低減の 2 つの対策がなされた．これ以後，この種の大きな事故 は起きていない. しかし, 長時間使用されたユニット も増加しており，長時間使用によるクリープ破断延性 の低下に起因する損傷も報告されている.7) そこで, 温 度，応力ともに厳しい条件にさらされる $1 \mathrm{CrMoV}$ 口
ー夕翼溝部の高温クリープ破断寿命の解析的評洒法に ついて検討した．特にクリープ状態での多重歯の荷重 分担率の変化ならびに応力レベルによって異なる破損 モードの違いを考虑に入れた。また解析精度の実験的 検証も実施した。

\section{2 多重歯翼溝部の解析的クリープ破断寿命 評価法}

Fig. 1 に多重歯翼溝部の解析的なクリープ破断寿命 評価法の概要を示す．またFig. 2 にぜい性クリープと 延性クリープの違いを考慮した切欠き材のクリープ破 断寿命評価法の概要を示す.なお, Fig. 2 の詳細説明 は別報に譫る.

\section{$2 \cdot 1$ 解析対象}

高中圧ロータサイドエントリ翼の翼溝肩部を想定し,

\footnotetext{
$\dagger \quad$ 原稿受理 平成元年 2 月27日 Received Feb. 27, 1989

* 正会員 三菱重工業(株)長崎研究所 長崎市飽の浦町, Nagasaki R \& D Center, Mitsubishi Heavy Industries, Ltd., Akunoura-machi, Nagasaki

三菱重工業(株)長崎研究所＼cjkstart長崎市飽の浦町, Nagasaki R \& D Center, Mitsubishi Heavy Industries, Ltd., Akunoura-machi, Nagasaki

*** 三菱重工業(株)原動機技術統括室 東京都港区芝, Power Systems Engineering Division, Mitsubishi Heavy Industries, Ltd., Shiba, Minato -ku, Tokyo
} 


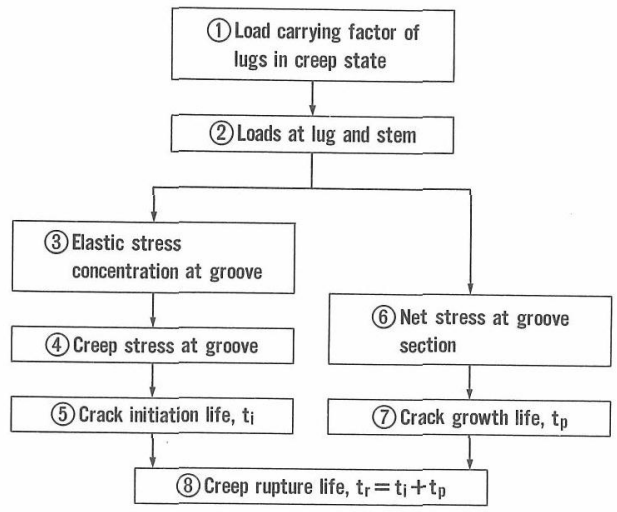

Fig. 1. Analytical creep rupture life prediction of multiple-lug rotor steeples.

(1) Object

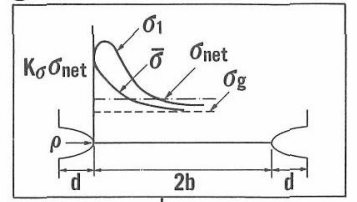

(2) Phenomena

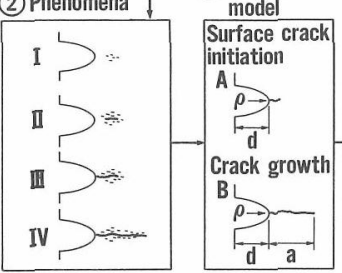

(4) Creep test

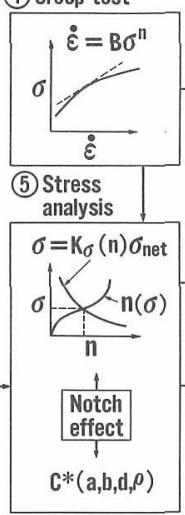

(6) Short term creep rupture test

Ductile creep Brittle

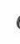

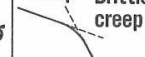

\section{$\rightarrow \mathrm{ti}_{\mathrm{i}}$}
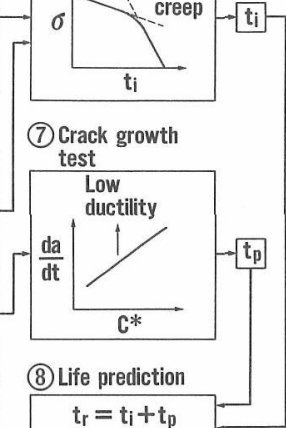

Fig. 2. Analytical prediction method of brittle and ductile creep rupture life of $1 \mathrm{CrMoV}$ notched thick plate.
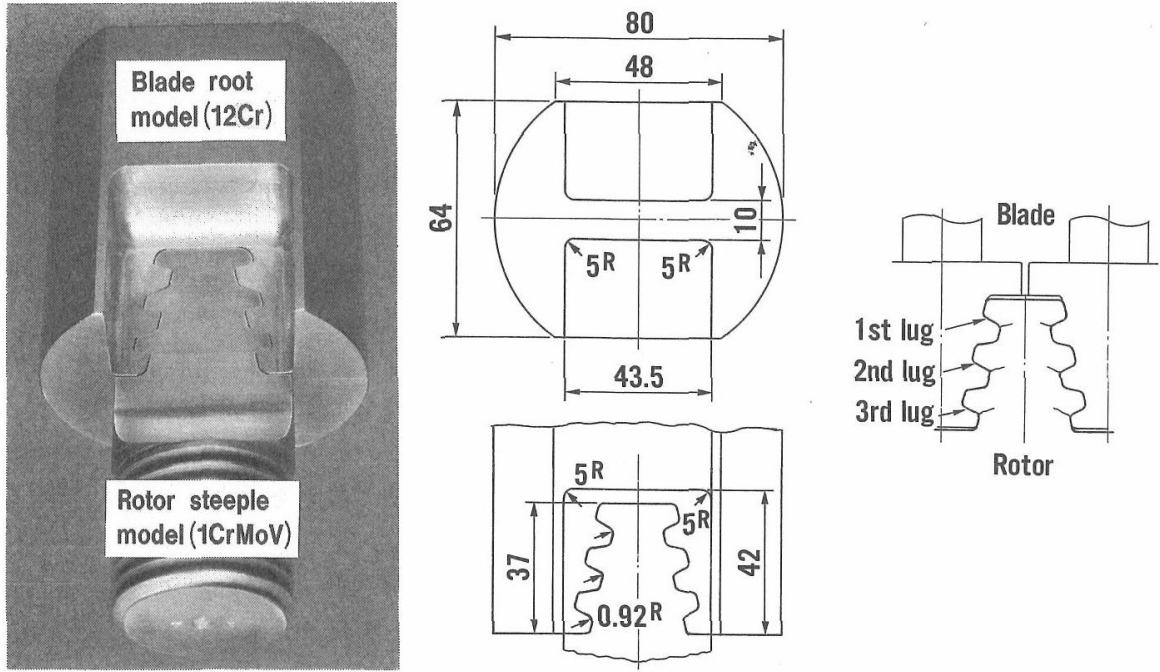

Fig. 3. Blade root and rotor steeple model.

Fig. 3 に示す翼根翼溝組合せモデルを製作し，これを 解析対象とした。ロー夕翼溝部を試験体に,ブレード 翼根部をホルダにした翼溝翼根モデルである。材料は,
ロータ翼溝モデルに $1 \mathrm{CrMoV}$ 鍛鋼を，ブレード翼根 モデルに $12 \mathrm{Cr}$ 鍛鋼を用いた。ロータ翼溝モデルの供 試材は 10 万時間使用後廃却した中圧ロータ 
Table I. Chemical composition.

$(\mathrm{wt} \%)$

\begin{tabular}{c|c|c|c|c|c|c|c|c|c}
\hline Material & $\mathrm{C}$ & $\mathrm{Si}$ & $\mathrm{Mn}$ & $\mathrm{P}$ & $\mathrm{S}$ & $\mathrm{Ni}$ & $\mathrm{Cr}$ & $\mathrm{Mo}$ & $\mathrm{V}$ \\
\hline $\mathrm{A}, \mathrm{B}$ & 0.30 & 0.23 & 0.74 & 0.012 & 0.008 & 0.35 & 1.10 & 1.16 & 0.24 \\
\hline
\end{tabular}

Table II. Heat treatment condition.

\begin{tabular}{c|r|c}
\hline Material & Heat treatment & Ramarks \\
\hline A & $\begin{array}{r}970^{\circ} \mathrm{C} \times 22 \mathrm{hrs} \mathrm{Fan.}+665^{\circ} \mathrm{C} \times 67 \mathrm{hrs} \mathrm{F.C.} \\
+630^{\circ} \mathrm{C} \times 47 \text { hrs F.C. }\end{array}$ & As-Removed \\
\hline B & $1010^{\circ} \mathrm{C} \times 13 \mathrm{hrs} \mathrm{Fan.}+680^{\circ} \mathrm{C} \times 25$ hrs A.C. & Re-Q.T. A \\
\hline
\end{tabular}

Note : After re-quenching, material $B$ were cooled according to the cooling rate simulated at the surface of a 800 $\mathrm{mm}$ diameter forging.

（1CrMoV 鍛鋼）の低温部から採取したものである. よって，経年劣化はないと考えられる．以下 Material A と称する (Table I 参照). また比較的短時間で切 欠き弱化しやすくなるように熱処理し直した材料 Material B も供試した (Table II 参照).

\section{$2 \cdot 2$ 定常クリープ状態での多重歯の荷重分担率}

高温クリープ変形による荷重分担率の変化は一般に 無視できない. また，比較的早く定常クリープ状態に なることから, Fig. 4 に示すように翼根と翼溝の歯と 幹をそれぞれ梁にモデル化し, 定常クリープ状態での 翼遠心荷重による引張り荷重分担率を求めた.すなわ $ち$, 第 $j$ 歯と第 $j+1$ 歯の各接点間の定常クリープ変 形速度が部材 1 (翼根) 側と部材 2 (翼溝) 側で等し いことから, 荷重分担率 $p_{i}(i=1, M)$ に関する方程 式 (1) が得られる.ただし，簡単のためにクリープひ ずみ速度は Norton 則 $\dot{\varepsilon}=B \sigma^{n}$ を仮定した。幹は引張 り変形を, 短いテーパ歯は曲げ変形, せん断変形と回 転変形を生じる．ところで, 定常クリープ状態での歯 のせん断変形や歯の根元の回転変形に対する評価式は 簡単には求まらない，そこで，短いテーパ歯を同一の 弾性変形を生じる等価な一様断面梁にモデル化し, こ れの定常クリープ状態での曲げ変形評価式で近似評価 した.

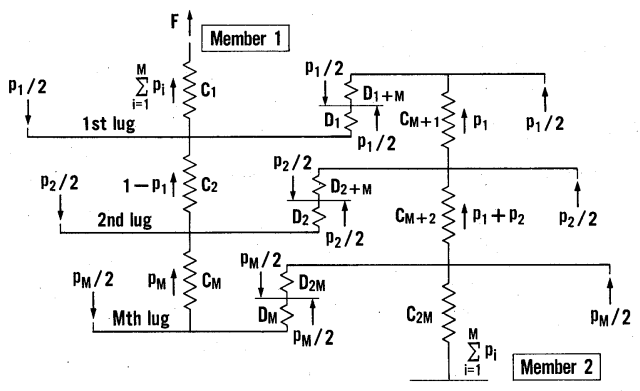

Fig. 4. Beam models for calculation of loadcarrying-factors of lugs in the steady creep state.

$$
\begin{gathered}
\left(p_{j+1}\right)^{n_{1}} D_{j+1}+\left(1-\sum_{i=1}^{j} p_{i}\right)^{n_{1}} C_{j+1}-\left(p_{j}\right)^{n_{1}} D_{j} \\
=\left(p_{j}\right)^{n_{2}} D_{j+M}+\left(\sum_{i=1}^{j} p_{i}\right)^{n_{2}} C_{j+M}-\left(p_{j+1}\right)^{n_{2}} D_{j+1+M} \\
j=1, \quad M-1
\end{gathered}
$$

ここで $n_{1}$ および $n_{2}$ はそれぞれ部材 1 と 2 の Norton 則の指数 $n$ である. また $D$ は幹のコンプライ アンスを, $C$ は歯のコンプライアンスを表す. 一方, 定義から荷重分担率 $p_{i}(i=1, M)$ に対して式 (2) が成 り立つ.

$$
\sum_{i=1}^{M} p_{i}=1
$$

したがって，式(1) と式 (2) から定常クリープ状態で の $M$ 個の歯の荷重分担率が求まる. Fig. 3 に示す翼 根翼溝組合せモデルの 3 個の歯の荷重分担率は, 弾性 状態では $p_{1}: p_{2}: p_{3}=0.26: 0.33: 0.41$ であったが, 定常クリープ状態では $0.32: 0.35: 0.33$ となり，ほぼ 一様化した．定常クリープ状態で多重歯の引張り荷重 分担率が一様化した理由は, 定常クリープ状態では各 歯の変形に比べて幹の変形が無視できることと, 各歯 の剛性に大きな差がない場合は Norton 則の指数 $n$ が 大きくなると各歯の荷重分担率は一様化するからであ る.

\section{$2 \cdot 3$ 歯底のクリープ応力}

歯底の局部弾性応力は各歯にかかる集中荷重による もの $\alpha_{b} \sigma_{0 b}$ と幹にかかる一様引張り荷重によるもの $\alpha_{m} \sigma_{0 m}$ とがある. 厳密にはそれぞれの最大応力発生位 置は若干ずれるが, 安全側にその和で評価した.

$$
\sigma_{e, \max }=\alpha_{b} \sigma_{0 b}+\alpha_{m} \sigma_{0 m} \equiv K_{t} \sigma_{0}
$$

ここで $\alpha_{b}, \alpha_{m}$ と $K_{t}$ は応力集中率を表し， $\sigma_{0 b}, \sigma_{0 m}$ と $\sigma_{0}$ は歯底の曲げ, 引張りそして全体としての公称 応力を表す.

歯底のクリープ応力は, 大路, 久保にようて提案 された小規模クリープ条件下の切欠き応力ひずみ予測 法, さ2) さらに日本鉄鋼協会高温強度研究委員会切欠き効 果試験分科会の方法等を参考にして式 (4)で評価した.

最大主応力 $\sigma_{1 c}: K \sigma \equiv \sigma_{1 c} / \sigma_{0}$

$$
=\left\{\begin{array}{cl}
K_{t} & \tau \leq \tau_{1} \\
f_{10}\left[K_{t} / \sqrt{n g_{0} g_{1} \tau}\right]^{2 /(n+1)} & \tau_{1} \leq \tau \leq \tau_{2} \\
f_{10}\left[K_{t}\right]^{2 /(n+1)} & \tau \geq \tau_{2}
\end{array}\right.
$$

相当応力 $\bar{\sigma}_{\mathrm{c}}: K_{\sigma}^{*} \equiv \bar{\sigma}_{\mathrm{c}} / \sigma_{0}$

$$
= \begin{cases}K_{t}^{*} & \tau \leq \tau_{1} \\ \bar{f}_{0}\left[K_{t} / \sqrt{n g_{0} g_{1} \tau}\right]^{2 /(n+1)} & \tau_{1} \leq \tau \leq \tau_{2} \\ \bar{f}_{0}\left[K_{t}\right]^{2 /(n+1)} & \tau \geq \tau_{2}\end{cases}
$$

ここで

$$
\begin{aligned}
& \tau=\mathrm{BE} \sigma_{0}^{n-1} t, \quad t: \text { 時間 } \\
& \tau_{1}=1 /\left[n g_{0} g_{1}\left(K_{t}^{*}\right)^{n-1}\right], \\
& \tau_{2}=1 /\left(n g_{0} g_{1}\right)
\end{aligned}
$$




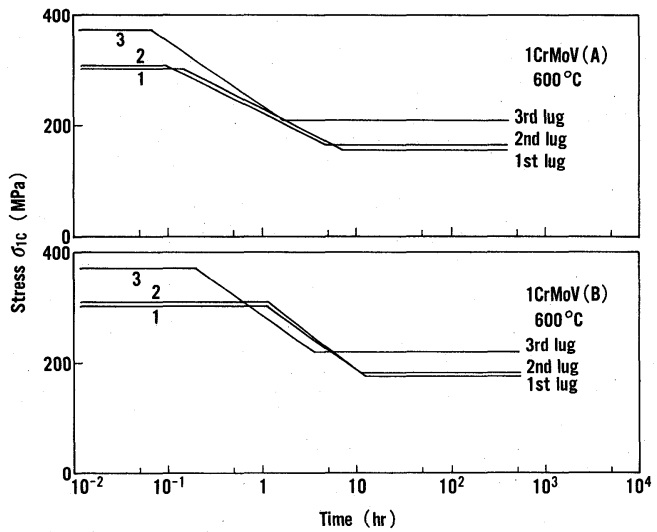

Fig. 5. Creep stress at groove root in rotor steeple model.

$$
\begin{aligned}
& f_{10}=\left(1-\nu+\nu^{2}\right)^{1 /(n+1)-1 / 2} \cdots \cdots . \text { 平面ひずみ } \\
& \bar{f}_{0}=f_{10} \sqrt{1-\nu+\nu^{2}} \\
& g_{0}=\left(1-\nu+\nu^{2}\right) /\left(1-\nu^{2}\right) \cdots \cdots \text { 平面ひずみ } \\
& g_{1}=9 \pi / 16 \\
& \nu: \text { ポアソン比 } \\
& K_{t}^{*}=K_{t} \sqrt{1-\nu+\nu^{2}} \cdots \cdots \text { 平面ひずみ } \\
& K_{t}: \text { 最大主応力ベースの理論弾性応力集中率 }
\end{aligned}
$$

なお, Norton 則の指数 $n$ は, 定常クリープ応力で のクリープ損傷を重視して，歯底の定常クリープ応力 $\sigma_{1 c}$ での值を用いた. すなわち式 (5) から定めた.

$$
\left.\begin{array}{l}
n=n(\sigma) \\
\sigma=K \sigma(n) \sigma_{0}
\end{array}\right\}
$$

また，厚肉モデルであるので，平面ひずみ状態を仮 定した。

Fig. 5 に $600^{\circ} \mathrm{C}$ でかつ $F=16 \mathrm{kN}$ の引張荷重下での 翼溝モデルの翼溝底のクリープ応力を示す．比較的早 く定常クリープ状態になることがわかる.

\section{$2 \cdot 4$ 翼溝のクリープき裂発生寿命}

クリープ損傷は式 (6) で算出し, $D_{c}=1$ のときの時 間をクリープき裂発生寿命 $t_{i}$ と評価した.

$$
D_{c}=\int d t / t_{r}
$$

ここで

$t_{r}=\operatorname{Min}\left(t_{r D}, \quad t_{r B}\right)$

$t_{r D}=f_{E L} /\left(n B \bar{\sigma}^{n}\right):$ 延性クリープ破断寿命

$t_{r B}=1 /\left((k+1) \vec{D} \sigma_{1}^{k}\right):$ ぜい性クリープ破断寿命

$f_{E L}=1-(1+E l)^{-n}$ : 有限クリープ伸びの影響係数

$B, n$ : Norton 則 $\dot{\varepsilon}=B \sigma^{n}$ の定数

$\bar{D}, k:$ Kachanov の損傷発展式 $\dot{\omega}=\bar{D} \sigma^{k} /(1-\omega)^{k}$ の定数

$E l:$ クリープ破断伸び

$\bar{\sigma}:$ von Mises の相当応力

$\sigma_{1}:$ 最大主応力

$2 \cdot 5$ 翼溝のクリープき裂進展寿命
クリープき裂進展則は式 (7)で評価した.

$$
\frac{d a}{d t}=C_{c}\left(C^{*}\right)^{m_{c}}
$$

ここで, $C_{c}, m_{c}$ は材料定数

$$
\begin{aligned}
& \left.\left.C^{*}=C_{0}^{*} f^{2}\right), 13\right) \\
& C_{0}^{*}=a B\left[\sqrt{3} \sigma_{\mathrm{net}} / 2\right]^{n+1} \pi \sqrt{n} \cdots \cdots \text { 平 } \\
& f=\left(K_{A}+K_{B}\right) / K_{0} \\
& K_{0}=\sigma_{\mathrm{net}} \sqrt{\pi a} \\
& K_{A}=\sigma_{A} \sqrt{\pi a} f_{A} \\
& K_{B}=\sigma_{B} \sqrt{\pi(a+d)} f_{B} \\
& \sigma_{\mathrm{net}}=(p+q) F /(2 b W) \\
& \sigma_{A}=(p / 2+q) F /(2 b W) \\
& \sigma_{B}=(p / 2) F /(2(b+d) W) \\
& f_{A}=\left(1+0.122(\cos x)^{4}\right) \sqrt{\tan x / x} \\
& x=\pi a /(2 b) \\
& f_{B}=(2 /(\pi y))\left(1.30-0.65 y-0.10 y^{2}\right. \\
& \left.\quad+0.45 y^{3}\right) / \sqrt{1-y} \\
& y=(a+d) /(b+d) \\
& a: \text { き裂長さ, } \quad b: \text { 幹の半幅 } \\
& d: \text { 歯の荷重点から歯底までの距離 } \\
& W: \text { 板厚, } \quad p F: \text { 歯の集中荷重 } \\
& q F: \text { 幹の一様引張り荷重 }
\end{aligned}
$$$$
C_{0}^{*}=a B\left[\sqrt{3} \sigma_{\text {net }} / 2\right]^{n+1} \pi \sqrt{n} \cdots \cdots \text { 平面ひずみ }
$$

また, クリープき裂進展寿命 $t_{p}$ は，き裂発生から $a_{c r}$ に至るクリープ破断までの寿命として式 (8)で評 価した。

$$
t_{p}=\Sigma\left(\Delta a /\left(C_{c}\left(C^{*}\right)^{m_{c}}\right)\right)
$$

ここで $a_{c r}=b\left(1-\sigma_{\text {net }} / \sigma_{\mathrm{U}}\right)$ : 限界き裂長さ $\sigma_{\mathrm{v}}:$ 引張り強さ

\section{$2 \cdot 6$ 翼溝のクリープ破断寿命}

翼溝のクリープ破断寿命 $t_{r}$ は，き裂発生寿命 $t_{i}$ と き裂進展寿命 $t_{p}$ の和として評価した。

$$
t_{r}=t_{i}+t_{p}
$$

\section{3 実 験 的 検 討}

\section{$3 \cdot 1$ 供試材料の基本特性}

供試材の基本特性の詳細は別報に譲る.なお Material B $\left(1010^{\circ} \mathrm{C}\right.$ 焼入れ) は Material A $\left(970^{\circ} \mathrm{C}\right.$ 焼入 れ）に比べて，かなりクリープ延性が低下し，またク リープき裂進展速度は 2 〜倍である.

\section{$3 \cdot 2$ 板状切欠き試験片による切欠きクリープ破断 特性}

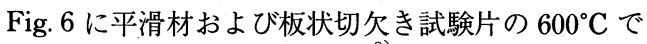
のクリープ破断試験結果を示す. Material B は極短 時間で切欠き弱化し， Material A も長時間側で切欠 き弱化する傾向が認められる. Fig. 6 中の小さな塗り つぶしの印は中途止め試験片 $\left(t / t_{r}=1 / 4,2 / 4,3\right.$ 14）を表すが, これらの板中央断面を組織観察した 結果を Fig. 7 に示す. クリープ破断寿命 $t_{r}$ に対して $t / t_{r}=1 / 4$ でもクリープボイドが既に切欠き底のすぐ 


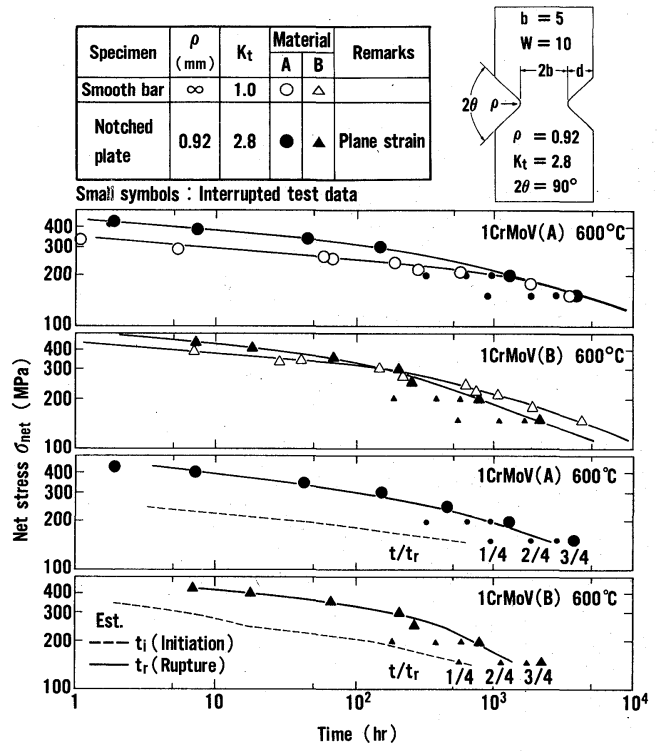

Fig. 6. Estimated time to creep crack initiation and creep rupture of $1 \mathrm{CrMoV}$ steel doubleedge-notched thick plate specimen.

内側に発生している.

$D_{c}=3 / 4$ の時点でみると, 高応力試験片では既に表 面き裂になって進展している，一方，低応力試験片で は Material A の場合にようやく表面き裂になった状 態であり，一方 Material B の場合はまだ内部き裂の 状態である．これらのことから応力が小さいほど，ま たクリープぜい化しやすい材料ほど，クリープ破断寿 命 $t_{r}$ に占めるクリープき裂発生寿命 $t_{i}$ は大きいこと がわかる。

また Fig. 6 には板状切欠き試験片のクリープ破断寿 命逆解析結果も示した。推定值と実験值と良い対応が あり，解析手法の妥当性が実証できた。なお解析的に 求めたクリープき裂発生寿命 $t_{i}$ は, クリープボイド が切欠き底表面から若干内側の部分に生じる時点に相 当していた.

\section{$3 \cdot 3$ 翼溝翼根組合せモデルのクリープ中途止め試 験片の組織観察}

$3 \cdot 3 \cdot 15450$ 時間経過後の板表面と溝底（レプリ 力観察） 板表面部のレプリカ観察結果によれば, Material A モデルの場合第 3 歯底が最もクリープ損 傷が大きく，クリープボイドの発生 $\rightarrow$ 連結 $\rightarrow$ 微小内 部き裂の発生過程まで進んでいる. 一方, Material B モデルの場合はさらにクリープ損傷は進行し，第 3 歯 底では内部き裂から表面き裂に成長している，また， 翼溝の溝底面を 0.1 0.2 mm 研磨してレプリカを採 取したところ，板表面レプリカ観察と同様クリープボ イドが検出できた。

$3 \cdot 3 \cdot 25450$ 時間後の板中央断面（実体観察）

\section{$\mathrm{CrMoV} 600^{\circ} \mathrm{C}$}

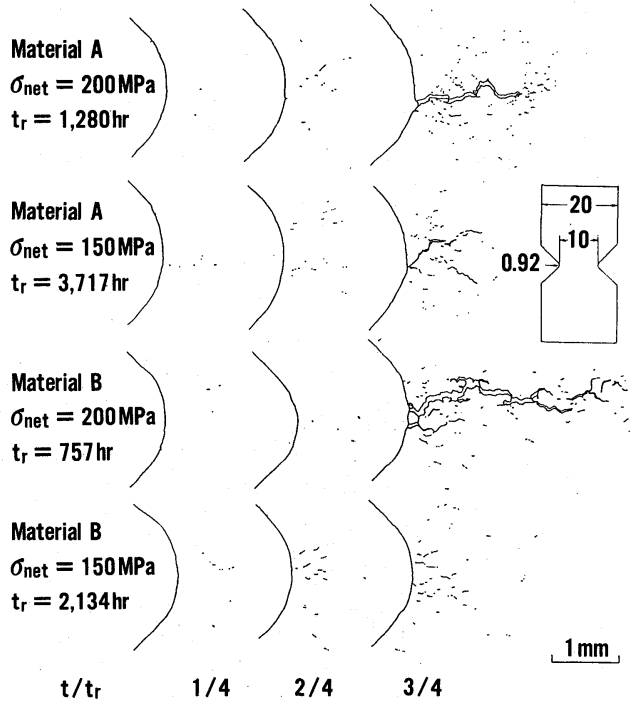

Fig. 7. Creep damage process at and near the notch of $1 \mathrm{CrMoV}$ steel double-edge-notched thickplate creep test specimen interrupted at $1 / 4$, $2 / 4,3 / 4$ of the creep rupture life.

代表例として, Fig. 8 に損傷の大きい Material B モデ ルの板中央断面のクリープ損傷状況を示す. 実体観察 の結果，以下のことが明らかになった。

(1) 熱処理条件の影響 Material A と B ともに典 型的なぜい性クリープ損傷形態であり，結晶粒界に 沿ってクリープボイドが発生・連結し，内部き裂に なった後に表面き裂に成長，進展している．また明ら かに Material B の方がクリープ損傷がひどく進行し ている．第 3 歯底では表面き裂の進展段階であり，そ のき裂長さは約 $2 \mathrm{~mm}$ である．き裂進展に伴い，クリ ープボイドの発生域は次第に狭くなっている. 一方, Material A の場合は第 3 歯底でもようやく微小内部 き裂から表面き裂に成長した段階である。

Fig. 6 と Fig. 7 から Material B の方がクリープ破断 寿命に占めるクリープき裂発生寿命が大きい傾向が認 められており，このことから Material B モデルの第 3 歯はクリープ破断寿命の末期的な段階にあると考え られる。

（2）応力状態の影響 板表面は板中央断面に比べる と, クリープ損傷は小さい. その大きな理由は, 板中 央断面は平面ひずみ状態に近く, 板表面は平面応力状 態に近いためと考えられる. 応力ひずみ状態の場合に のみ, 最大主応力のピーク值が歯底から若干内側に生 じ，ぜい性クリープボイドの発生域と良い対応があ る. 一方, 平面応力状態では最大主応力も相当応力も 歯底に生じる．板表面でも歯底から若干内側に入った 部分からクリープボイドが発生しているが, これはむ 


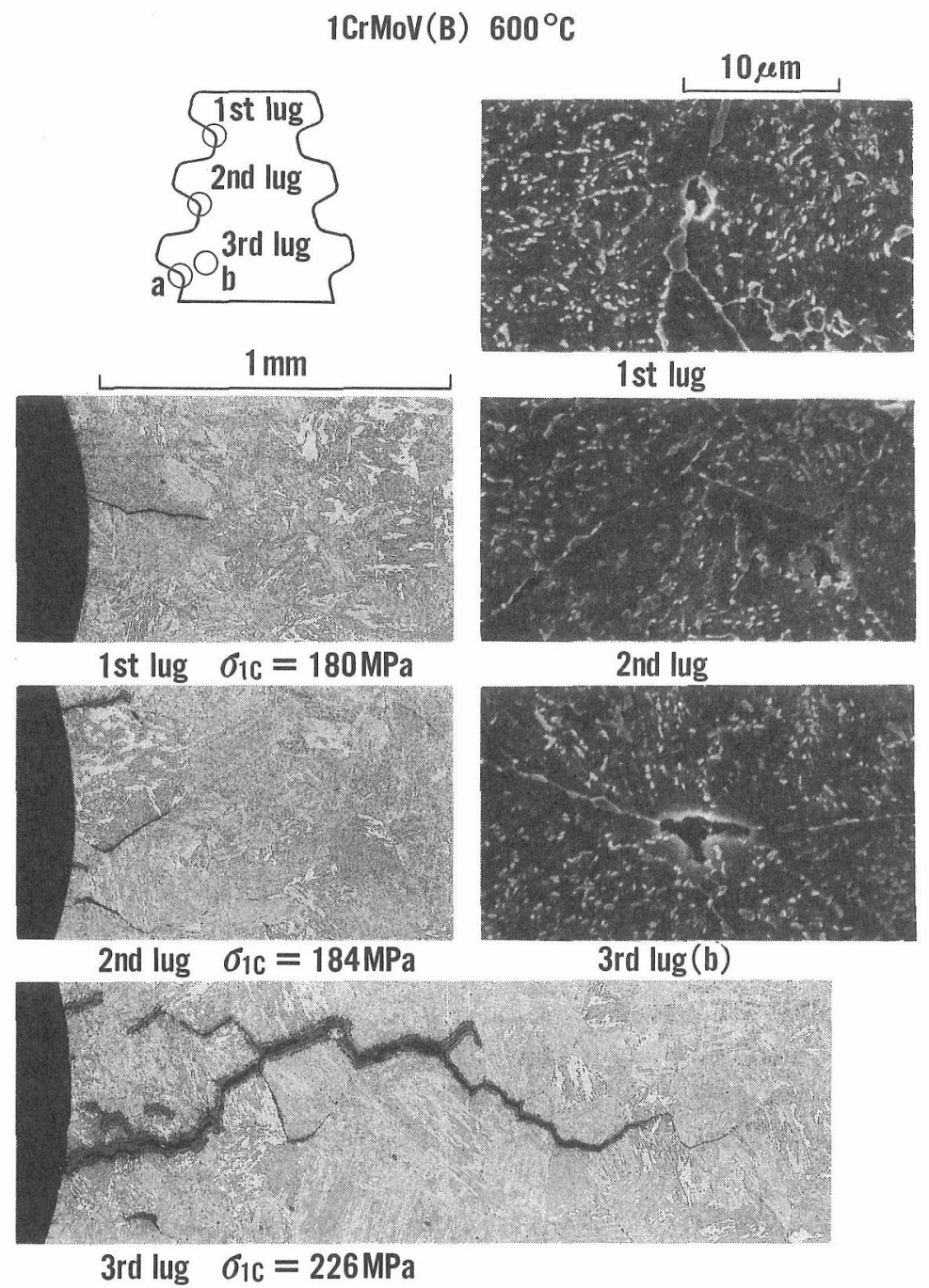

Fig. 8. Creep damage at and near the groove root of $1 \mathrm{CrMoV}$ steel rotor steeple model interrupted at $5450 \mathrm{hr}$.

$\left\lceil 600^{\circ} \mathrm{C}\right.$, Material B, $\rho=0.92 \mathrm{~mm}, F=16 \mathrm{kN}$, at the mid-thickness $]$.

しろ，完全な平面応力状態でなく，板内部の影響を受 けて平面ひずみと平面応力の中間状態にあると考えら れる。

(3) 応カレベルの影響 Fig. 5 に示したように歯底 の応力レベルは第 3 歯が最大であり，次いで第 2 歯, 第 1 歯となる.ただし第 2 歯と第 1 歯の応力レベルは 大差はない。実際のクリープ損傷状態もこの順序であ り，推定值と実験值とは良い対応がある。

\section{3・4. 解析的な寿命予測と組織観察との対応}

Fig. 9 に翼溝翼根組合せモデルの翼溝クリープ寿命 消費率 $t / t_{r}$ の予測結果を示す。き裂発生寿命 $t_{i}$ とク リープ破断寿命 $t_{r}$ を推定精度 $\frac{1}{2} \sim 2$ としてバンド表 示した. なお，応力状態は平面ひずみを仮定し，有効
応力は最大主応力を仮定した。これと組織観察結果を 比較すると, 各歯の解析的なクリープ破断寿命推定值 は実験值と比較的良く一致している。また解析的なク リープき裂発生寿命推定值はクリープボイドの発生時 期と良い対応があることがわかった。

$$
4 \text { 結訔 }
$$

長期使用によってクリープ延性低下する $1 \mathrm{CrMoV}$ 高中压ロータ翼溝のクリープ破断寿命予測法を検討し た。また低クリープ延性材と高クリープ延性材の 2 鋼 種を供試して $600^{\circ} \mathrm{C}$ で板状切欠きクリープ破断試験 ならびに翼溝翼根組合せモデルクリープ中途止め試験 を実施した結果，下記のことが明らかになった。

1 ) 翼根と翼溝の歯と幹をそれぞれ梁にモデル化し, 

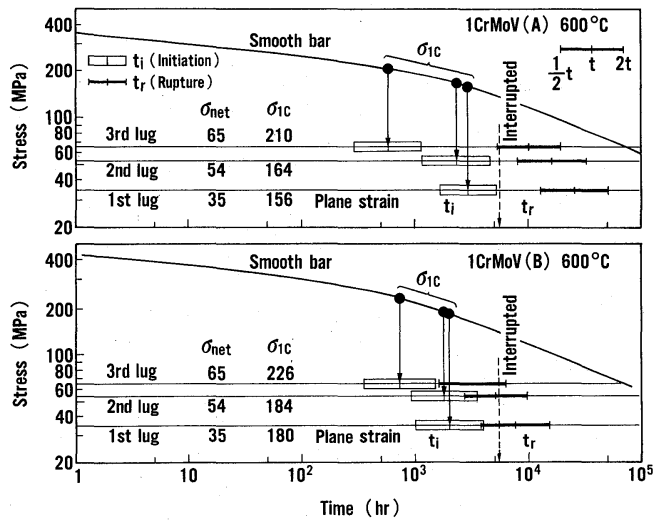

Fig. 9. Analytical creep life prediction of rotor steeple models.

定常クリープ状態での翼遠心荷重による多重歯の引張 り荷重分担率の簡易推定式を導いた。解析の結果, 弾 性状態とは異なり, 定常クリープ状態では各歯の剛性 に大きな差がない場合には多重歯の引張り荷重分担率 は一様化の傾向があることが明らかになった。

2 ）歯底の局部応力は各歯にかかる集中荷重による ものと幹にかかる一様引張荷重によるものの和である. そこで等価な応力集中率を導入し, 大路, 久保の小規 模クリープ条件下の切欠き応力ひずみ予測法を拡張し て用い, クリープ緩和過程を評価した. 特に, 定常ク リープ状態でのクリープ損傷を重視し, Norton 則の 指数 $n$ は歯底の定常クリープ応力での值を用いた. このとき, クリープひずみ速度の応力依存性を考慮に 入れたことがポイントである. その結果, 歯底のクリ ープ応力とクリープ損傷量が詳細に評価可能となった.

3 ) $1 \mathrm{CrMoV}$ ロー夕翼溝のクリープ破断寿命は, 上記の定常クリープ状態での多重歯の荷重分担率と歯 底のクリープ応力ならびに延性効果を考慮して求めた クリープき裂発生寿命とクリープき裂進展寿命の和と して評価すれば，実用上十分な精度で合理的に評価で きることが確認された.

4) 板状切欠きクリープ破断試験ならびに翼溝翼根 組合せモデル中途止め試験の結果より, 応力が小さい ほど，またクリープぜい化しやすい低クリープ延性材 ほど，クリープ破断寿命に占めるクリープき裂発生寿
命は大きいことが明らかになった．また，解析的に求 めたクリープき裂発生寿命は, 実験的にはクリープボ イドが切欠き底表面から若干内側の部分に生じる時点 に相当していることが明らかになった。

（昭和63年12月15日＼cjkstart第26回高温強度シンポジウムにて講演）

\section{参 考 文 献}

1) J. D. Conrad and N. L. Mochel, Trans. ASME, 80, 1210 (1958).

2 ) D. N. Frey, ASTM STP 128, 131 (1952).

3 ) W. Siegfried, ASTM STP 128, 93 (1952).

4 ) E. A. Davis and M. J. Manjoine, ASTM STP 128, 67 (1952).

5 ) M. J. Manjoine, Proc. of Joint International Conference on Creep, 7.37 (1963).

6 ) N. Cheruvu, W. E. Howard and O. W. Beasley, ASME 85-JPGC-Pwr-29 (1985).

7 ) V. P. Swaminathan, N. S. Cherubu, A. Saxena and P. K. Liaw, EPRI-86001-41 (1986).

8 ) K. Ando, Y. Takeda and K. Takezoe, ASME PVP-Vol. 163, 115 (1989).

9 ) 大路清嗣, 久保司郎, 平原裕明, 日本機械学会論文集, 50, 1583 (1984).

10) S. Kubo and K. Ohji, Proc. of JSME-IMech E-ASME -ASTM International Conference on Creep, 417 (1986).

11）日本鉄鋼協会, 切欠き効果試験分科会成果報告書 (1985).

12) H. C. Argo, J. E. De Long, K. Kadoya, M. Nakamura and K. Ando, ASME 84-JPGC-Pwr-15 (1984).

13）角家義樹, 川本和夫, 中村 誠, 安藤 清, 後藤 徹, 岩本啓一, 藤田明次, H. C. Argo, 三菱重工技報，21，5， 654 (1984).

14) M. Y. He and J. W. Hutchinson, Trans. ASME, Ser. E., Vol. 48, 830 (1981).

15) H. Tada, P. C. Paris and G. R. Irwin, "The Stress Analysis of Cracks Handbook", 2nd Edition (1985) Del Resarch Corporation.

16）竹田頼正, 田北勝彦, 金子 晨, 竹添堅三郎, 日本材料 学会第35期学術講演会前刷集, 232 (1986)

17）竹田頼正, 田北勝彦, 金子 晨, 竹添堅三郎, 日本材料 学会第24回高温強度シンポジウム前刷集, 137 (1986). 